\title{
Ovarian Steroid Treatment Decreases Corticotropin-Releasing Hormone (CRH) mRNA and Protein in the Hypothalamic Paraventricular Nucleus of Ovariectomized Monkeys
}

\author{
Cynthia L Bethea*,',2 and Maria Luisa Centeno' \\ 'Division of Reproductive Sciences, Oregon National Primate Research Center, Oregon Health and Science University, Beaverton, OR, USA; \\ ${ }^{2}$ Division of Neuroscience, Oregon National Primate Research Center, Oregon Health and Science University, Beaverton, OR, USA
}

\begin{abstract}
Corticotropin-releasing hormone $(\mathrm{CRH})$ gene and protein expression were examined in the paraventricular nucleus (PVN) of ovariectomized female macaques treated with placebo or hormone therapy $(\mathrm{HT})$ consisting of either estrogen (E) for 28 days, or progesterone (P) for the last 14 of 28 days, or $E$ for 28 days supplemented with P for the last 14 of 28 days using Silastic capsules implanted s.c. in the periscapular region ( $n=4$ /group). Perfusion fixed sections $(25 \mu \mathrm{m})$ at five levels of the PVN (rostral to caudal at $250 \mu \mathrm{m}$ intervals) were immunostained (ICC) with an antibody to human $\mathrm{CRH}$ or processed in an in situ hybridization (ISH) assay with a monkey specific $\mathrm{CRH}$ riboprobe. The immunostained $\mathrm{CRH}$-positive area was quantified with a Marianas Stereology Workstation and Slidebook 4.2. There was a significant decrease in the immunological $\mathrm{CRH}$ signal with $\mathrm{E}, \mathrm{P}$, and $\mathrm{E}+\mathrm{P}$ treatment as measured by total or average pixels and microns (analysis of variance (ANOVA), $p<0.002$; Student-Newman-Keul's post hoc test versus placebo control group, $p<0.05$ ). There was also a decrease in the number of detectable $\mathrm{CRH}$ neurons (ANOVA, $p<0.03$ ) with HT. The sections processed for ISH were exposed to autoradiographic films. The CRH mRNA signal was analyzed with NIH Image. The average optical density and positive pixel area of the CRH mRNA signal was significantly suppressed by ovarian HT (ANOVA $p<0.002 ;$ StudentNewman-Keul's post hoc test versus placebo control group, $p<0.05)$. In summary, I month of stable treatment with a moderate dose of $\mathrm{E}, \mathrm{P}$ or $\mathrm{E}+\mathrm{P}$ significantly reduced $\mathrm{CRH}$ mRNA and protein in the PVN of ovariectomized monkeys. These results suggest that this hormone treatment regimen may increase stress resilience in surgically menopausal primates.
\end{abstract}

Neuropsychopharmacology (2008) 33, 546-556; doi: I 0.I 038/sj.npp. I 30 I442; published online I6 May 2007

Keywords: estrogen; progesterone; macaques; corticotropin; serotonin; hypothalamus

\section{INTRODUCTION}

The hypothalamic paraventricular nucleus (PVN) contains corticotropin-releasing hormone $(\mathrm{CRH})$ neurons and receives a robust serotonergic innervation, which regulates CRH production (Petrov et al, 1992; Hanley and Van de Kar, 2003). CRH in the PVN is elevated by stress and it has been implicated in the etiology of depression (Morimoto et al, 1993; Nemeroff, 2004). The role of ovarian hormones in depression and stress sensitivity or resilience is of great interest for women transitioning through menopause and questioning the use of hormone therapy (HT).

*Correspondence: Dr CL Bethea, Divisions of Reproductive Sciences and Neuroscience, Oregon National Primate Research Center, ONPRC/OHSU, 505 NW I 85th Ave, Beaverton, OR 97006, USA, Tel: + I 503690 5327, Fax: + I 503690 5384, E-mail: betheac@ohsu.edu Received 3 January 2007; revised 30 March 2007; accepted 3 April 2007
In animal models, HT with natural estrogen (E) and progesterone $(\mathrm{P})$ decreases aspects of stress reactivity, and increases resilience, on a cellular level as well as, on an organismal level (Kloet, 1995; Matthews et al, 1998). However in rodents, acute $\mathrm{E}$ treatment increased CRH in the PVN in some studies (Li et al, 2003), but decreased CRH in the PVN when administered in a chronic low dose (Dayas et al, 2000). In primates, administration of $\mathrm{E}$ in a manner like the endogenous preovulatory $\mathrm{E}$ surge increased CRH in the PVN (Roy et al, 1999).

We have shown that the ovarian steroids, $\mathrm{E}$ and $\mathrm{P}$, alter gene and protein expression in serotonin neurons in a manner that indicates serotonin neurotransmission is elevated (Bethea et al, 2002). This action of $\mathrm{E}$ and $\mathrm{P}$ would elevate mood and increase stress resilience. Thus, it seemed counterintuitive that HT would increase both stress resilience and $\mathrm{CRH}$. We reasoned that the $\mathrm{E}$ surge paradigm in primates may be similar to acute $\mathrm{E}$ treatment in rats and hence, in this study we questioned the effect of chronic 
low-dose HT on CRH expression in the PVN of non-human primates.

Estrogen receptor beta $(\mathrm{ER} \beta)$ has been observed in rodent $\mathrm{CRH}$ neurons (Laflamme et al, 1998), but ER $\alpha$ been detected in human CRH neurons (Bao et al, 2005). Moreover, the human CRH promoter region contains five half ERE sites (Vamvakopoulos and Chrousos, 1993). Thus, ovarian HT could alter CRH production either (a) indirectly by acting on serotonin input to $\mathrm{CRH}$ neurons, or (b) directly by acting through ER in CRH neurons.

In our model of surgical menopause with and without HT, we achieve stable and moderate serum concentrations of $\mathrm{E}$ and $\mathrm{P}$ via s.c. Silastic capsules. In this study, CRH mRNA and protein expression were examined in ovariectomized macaques treated with placebo, $\mathrm{E}, \mathrm{P}$ or $\mathrm{E}+\mathrm{P}$ for 1 month.

\section{MATERIALS AND METHODS}

The Institutional Animal Care and Use Committee of the Oregon National Primate Research Center (ONPRC) approved this study.

\section{Animals for Immunocytochemistry}

Sixteen adult female rhesus monkeys (Macaca mulatta) were ovariectomized and hysterectomized (spayed) by the surgical personnel of ONPRC according to accepted veterinary protocol, approximately 3-6 months before assignment to this project. All animals were born in Oregon, were aged between 7 and 14 years, weighed between 4 and $8 \mathrm{~kg}$, and were in good health. ONPRC operates with a lease for fee arrangement. Thus, the animals were previously used in select reproductive protocols in which ovariectomy was the final step before releasing the animals back into the available pool.

Animals were either treated with placebo (ovx-control group; $n=4$ ), or treated with $\mathrm{E}$ for 28 days (E group; $n=4$ ), or treated with placebo for 14 days and then treated with $\mathrm{P}$ for 14 days (P group; $n=4$ ), or treated with $\mathrm{E}$ for 28 days and supplemented with $\mathrm{P}$ for the final 14 of the 28 days $(\mathrm{E}+\mathrm{P}$ group; $n=4)$. The placebo treatment of the ovxcontrol monkeys consisted of implantation with empty silastic capsules (s.c.) on days 0 and 14. The E-treated monkeys were implanted (s.c.) with one $4.5-\mathrm{cm}$ E-filled silastic capsule (i.d. 0.132 inches.; o.d. 0.183 inches.; Dow Corning, Midland, MI) on day 0 and an empty capsule on day 14. The E + P-treated group received an E-filled capsule, and 14 days later, received one 6-cm P capsule. The Ptreated group received an empty silastic capsule, and 14 days later received a P-filled capsule. All capsules were placed in the periscapular area under ketamine anesthesia (ketamine $\mathrm{HCl}, 10 \mathrm{mg} / \mathrm{kg}$, s.c.; Fort Dodge Laboratories, Fort Dodge, IA).

The E capsule was filled with crystalline estradiol (1,3,5(10)-estratrien-3,17-b-diol; Steraloids, Wilton, NH). The $\mathrm{P}$ capsule was filled with crystalline P (4-pregnen-3,20 dione; Steraloids).

\section{Euthanasia}

The monkeys were euthanized at the end of the treatment periods according to procedures recommended by the Panel on Euthanasia of the American Veterinary Association. Each animal was sedated with ketamine in the home cage, transported to the necropsy suite, given an overdose of pentobarbital $(25 \mathrm{mg} / \mathrm{kg}$, i.v.), and exsanguinated by severance of the descending aorta.

\section{Tissue Preparation}

The left ventricle of the heart was cannulated and the head of each animal was perfused with 1 liter of saline followed by 7 liters of $4 \%$ paraformaldehyde in $3.8 \%$ borate, $\mathrm{pH} 9.5$ (both solutions made with DEPC-treated water $(0.1 \%$ diethyl pyrocarbonate) to minimize RNase contamination). The brain was removed and dissected. Tissue blocks were post-fixed in $4 \%$ paraformaldehyde for $3 \mathrm{~h}$, then transferred to $0.02 \mathrm{M}$ potassium phosphate-buffered saline (KPBS) containing $10 \%$, followed by $20 \%$ glycerol and $2 \%$ dimethyl sulfoxide at $4{ }^{\circ} \mathrm{C}$ for 3 days to cryoprotect the tissue. After infiltration, the block was frozen in isopentene cooled to $-55^{\circ} \mathrm{C}$, and stored at $-80^{\circ} \mathrm{C}$ until sectioning, which occurred within 3 months of storage. Sections $(25 \mu \mathrm{m})$ were cut on a sliding microtome, mounted on Superfrost Plus slides (Fisher Scientific, Santa Clara, CA), dehydrated under vacuum overnight and then frozen at $-80^{\circ} \mathrm{C}$ until processing for in situ hybridization (ISH) and ICC.

\section{Immunocytochemistry}

A bath of antigen retrieval (AR) buffer (Vector Laboratories, Burlingame, CA) was heated to near boiling in a pressure cooker. Sections were removed from $-80^{\circ} \mathrm{C}$ storage and immersed in the hot AR buffer. The pressure cooker was sealed and heated until the rocker released steam (approximately $6 \mathrm{~min}$ ). The sections were boiled in AR buffer for $1 \mathrm{~min}$ after steam release occurred. Sections were removed, immersed in water for $5 \mathrm{~min}$, washed in KPBS buffer four times for $15 \mathrm{~min}$ each, immersed in methanol plus $10 \%$ hydrogen peroxide for $10 \mathrm{~min}$, washed in KPBS buffer four times for $15 \mathrm{~min}$ each and then incubated with the following blocking solutions: Vector normal goat serum (NGS) for $30 \mathrm{~min}$; Vector Avidin for $20 \mathrm{~min}$; Vector Biotin for $20 \mathrm{~min}$; $1 \%$ human $\alpha$-globulin in KPBS for $30 \mathrm{~min}$. Sections were then incubated for $48 \mathrm{~h}$ in antibody to CRH (gift of Dr. Wylie Vale, Salk Institute, La Jolla, CA). The CRH antibody was diluted $1 / 3000$ in $0.1 \%$ human $\alpha$-globulin-KPBS. Sections were then rinsed in KPBS buffer four times for $15 \mathrm{~min}$ each, incubated in vector biotylinated goat anti-rabbit serum for $60 \mathrm{~min}$, washed in KPBS buffer four times for $15 \mathrm{~min}$ each, incubated with vector $A B C$ reagent for $60 \mathrm{~min}$, washed in KPBS buffer four times for $15 \mathrm{~min}$ each, washed in Tris buffer, $\mathrm{pH} 7.6$ for $5 \mathrm{~min}$, incubated with DAB $(100 \mathrm{mg} / 200 \mathrm{ml}$ Tris- $\mathrm{HCl}$ buffer, $\mathrm{pH}$ 7.6) plus $80 \mu \mathrm{l}$ of $30 \%$ hydrogen peroxide for $20 \mathrm{~min}$, washed in Tris buffer for $5 \mathrm{~min}$, washed in KPBS buffer for $5 \mathrm{~min}$, and dehydrated through a graded series of ethanols, xylene, and Histoclear. Sections were mounted under glass with DPX.

\section{Stereological Analysis of Immunostaining}

Sections were anatomically matched between animals using anatomical reference points. A Marianas stereological 
workstation with Slidebook 4.2 was used for analysis. Each section was examined and guide points demarcating the PVN area were entered. The workstation captured multiple $\times 10$ images across the span of the PVN and built a $\times 10$ montage of the entire area. The software then segmented the montage on the basis of the signal density. The CRH positive neurons were highlighted and the area covered by highlight was computed in pixels and microns. In addition, the segmented pixels were filtered and objects between 5 and 100 voxels were counted. This corresponds to the number of CRH neurons. Finally, the area of the PVN that was analyzed was obtained. The values were recorded for 5 sections through the PVN of each animal and then subjected to further statistical analysis.

\section{In Situ Hybridization}

The protocol and buffers for the ISH assay have been published previously (Gundlah et al, 1999; Sanchez et al, 2005). A recombinant partial cDNA clone of the CRH gene was constructed using forward and reverse primers that produced a $202 \mathrm{bp}$ segment corresponding to the region that codes for the CRH peptide from human (NM_000756). The cDNA was generated by RT-PCR using hypothalamic rhesus macaque mRNA as template. The PCR product was ligated into a pGEM-T vector and amplified. Radiolabel antisense and sense riboprobes were generated using ${ }^{35} \mathrm{~S}$-labeled UTP. For sense riboprobe, linearization was achieved with $\mathrm{NcoI}$ and transcription was achieved with SP6 Polymerase. For antisense riboprobe, linearization was achieved with NotI and transcription with T7 polymerase. The sections were hybridized at $50^{\circ} \mathrm{C}$ and the final three high stringency washes $(2 \times, 2 \times$, and $0.1 \times \mathrm{SSC})$ were at $70^{\circ} \mathrm{C}$. The sections were exposed to Biomax MR film (Kodak, Rochester, NY) for 5 days.

\section{Analysis of CRH mRNA signal on Autoradiograms}

After exposure to the sections, the autoradiographic films were developed and images were video-captured and digitized using the NIH Image Program. For each anatomical level, the largest representation of the nucleus was chosen from amongst all of the animals. An outline was placed over the chosen nucleus and the exact dimensions were recorded. This template was then applied to all other animals. The average gray-scale optical density (OD) and number of pixels was obtained and statistically compared as described below.

\section{Hormone Assays}

Assays for $\mathrm{E}$ and $\mathrm{P}$ were performed utilizing a Roche Diagnostics 2010 Elecsys assay instrument. Before these analyses, measurements of estradiol, and $\mathrm{P}$ on this platform were compared to traditional RIAs as reported previously (Bethea et al, 2005b).

\section{Statistics}

The CRH signal on the autoradiograms was measured in positive pixel area and in OD. The measurements from each section containing the PVN were compared at each level between groups. The levels for each animal were then averaged generating one value for the entire PVN for each animal representing average signal per section. Then, the individual animal values for each treatment were averaged so the deviation around the mean is related to the variation between individual animals. The averages were compared between treatment groups with ANOVA followed by Student-Newman-Keul's post hoc pairwise comparison.
1

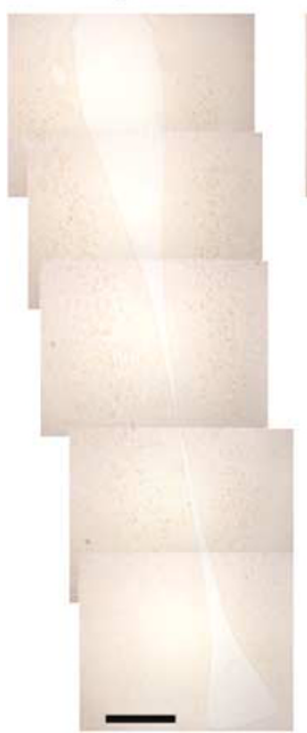

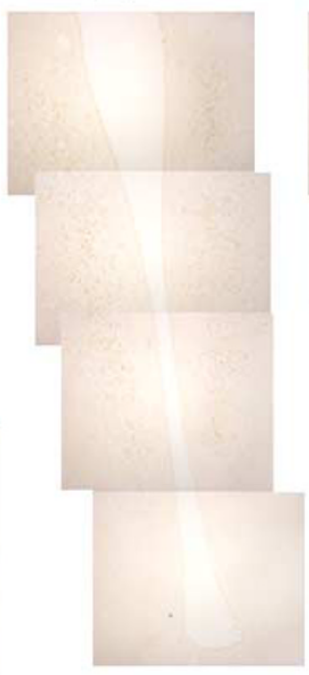

3

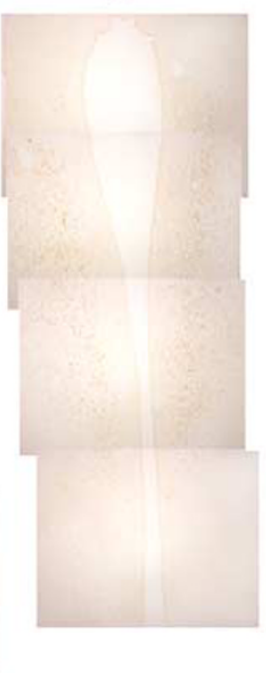

4

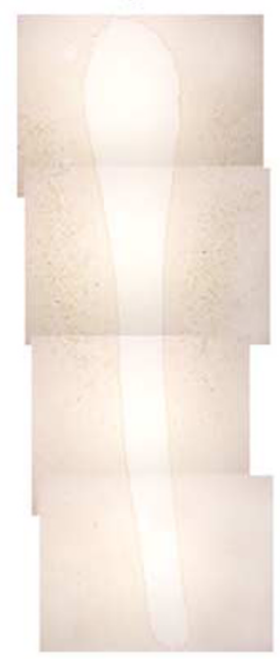

5

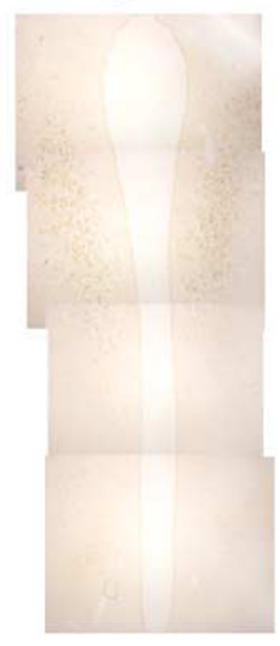

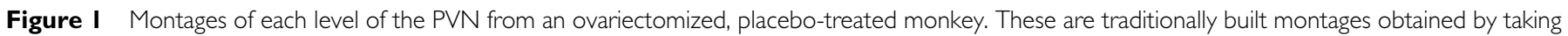
individual pictures on a Zeiss brightfield microscope and then manually assembling the pictures. This process is done automatically by the stereology microscope, but it is difficult to see the $\mathrm{CRH}$ neurons in stereology photomicrographs at low magnification. It is important to remember that the primate PVN is a very large structure and to capture the entire field requires zoom out to low magnification, which in turn, precludes the ability to sharply see individual neuronal characteristics. Individual neurons are illustrated in Figure 2. Scale bar, $500 \mu \mathrm{m}$. 
To quantitate the immunohistochemical CRH signal, Slidebook 4.2 segmented each section into CRH-positive pixels versus background and then computed the area of the $\mathrm{CRH}$ staining in pixels and in microns. This information was further computed in two ways. First, the average pixels or microns per section were obtained at each individual level. Then, the average number of pixels or microns per section was obtained for each animal and the individual animal means were further averaged for the overall average area of CRH-positive staining per section. This is called the 'averaging analysis.' However, the PVN varies significantly in size from level to level and this could increase the variance when obtaining the average $\mathrm{CRH}$ area per section. Therefore, we examined the total CRF-positive area of the entire PVN. Thus, in the second analysis, the area of CRH staining in the five levels was summed for each animal, indicating the total positive pixels or microns per animal. Then, the individual animal sums were averaged for each group to obtain the overall group mean of the total CRH signal. This is called the 'total analysis.'

Finally, using the segmentation tool on a defined area of the PVN and the software to discriminate objects of defined size, the CRH-positive cells were counted at each level. In addition, the size of the defined area was recorded.
The group means were compared with ANOVA followed by Student-Newman-Keul's post hoc pairwise comparison. Analyses were conducted using the Prism statistic program (GraphPad, San Diego, CA) A confidence level of $p<0.05$ was considered significant.

\section{RESULTS}

Serum E concentrations $(\mathrm{pg} / \mathrm{ml})$ equaled $5.8 \pm 0.8$, $122.8 \pm 50.9,8.6 \pm 11.9$, and $67.6 \pm 10.9$ in ovx, E-, P-, and $\mathrm{E}+\mathrm{P}$-treated animals, respectively. Serum $\mathrm{P}$ concentrations $(\mathrm{ng} / \mathrm{ml})$ equaled $0.23 \pm 0.1,0.16 \pm 0.03,9.58 \pm 1.48$, and $9.59 \pm 1.7$ in ovx, E-treated, P-treated, and E+P-treated animals, respectively.

Figure 1 illustrates the five levels of the PVN that were subjected to analysis with montages of each level from an ovx-placebo-treated monkey. It is difficult to see the CRH neurons in the stereology color montages. Therefore, the sections were photographed on a Zeiss brightfield microscope and traditional montages were built to better reveal the CRH neurons. These sections are $250 \mu \mathrm{m}$ apart. The section that is $250 \mu \mathrm{m}$ rostral to level 1 contained the beginning of the PVN, which in the primate starts at

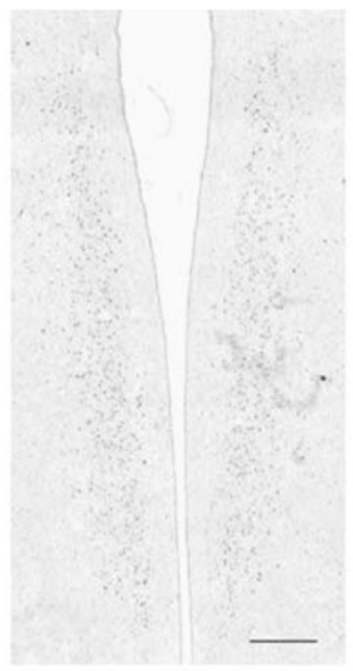

OVX

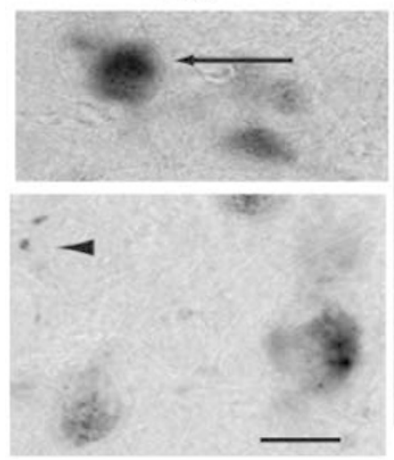

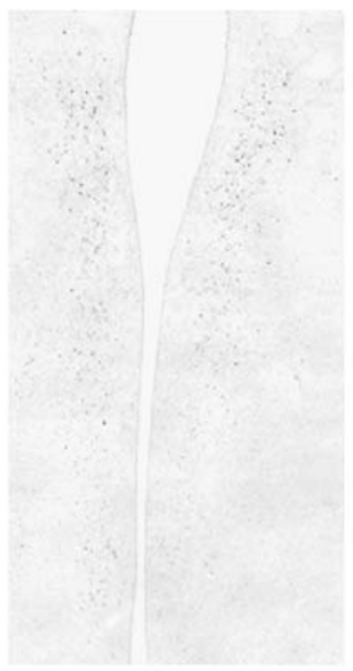

E

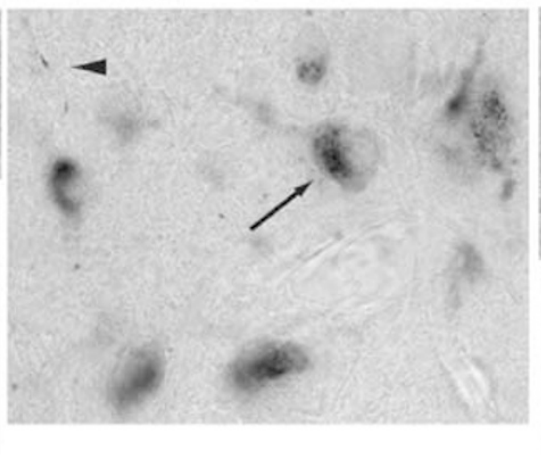

P
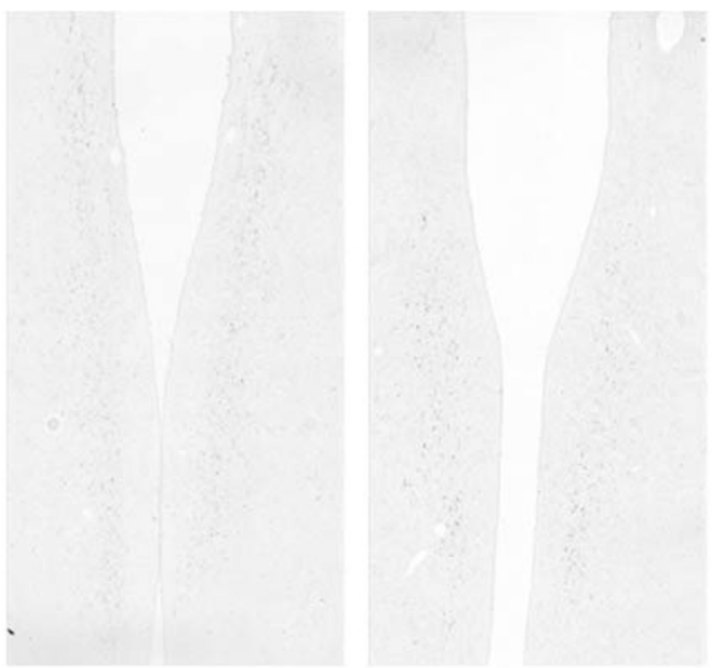

$\mathrm{E}+\mathrm{P}$

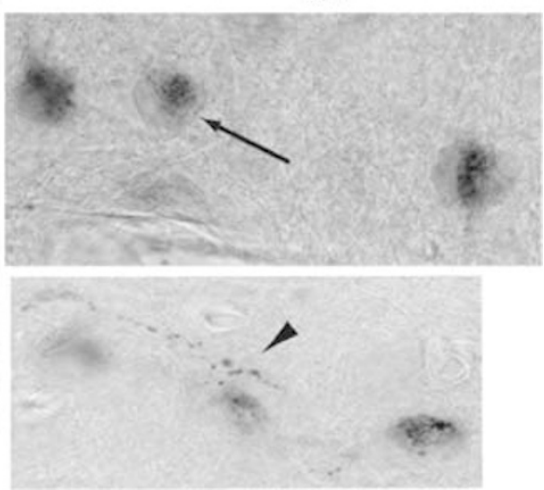

Figure 2 Stereology montages $(\times 10)$ of level I of the PVN from ovariectomized monkeys treated with placebo, E, P or E + P. The top panels show the $\mathrm{CRH}$ immunostaining in black and white. The $\mathrm{CRH}$ signal was segmented from background and the area of the signal was computed in pixels and microns for further quantitative analysis. Scale bar, $500 \mu \mathrm{m}$. The bottom panels show high-magnification $(\times 630)$ images of $\mathrm{CRH}$ neurons (arrows) and $\mathrm{CRH}$ beaded fibers (arrowheads) in the PVN of an ovariectomized-placebo-treated monkey. Scale bar, $10 \mu \mathrm{m}$. 
the bottom of the 3rd ventricle and varies significantly from animal to animal. The section that is $250 \mu \mathrm{m}$ caudal to level 5 contained little or no CRH neurons. Thus, these five levels were the most consistent, they spanned $1.125 \mathrm{~mm}$ of the hypothalamus and contained the majority of the CRH neurons.

Figure 2 illustrates the immunohistochemical staining for $\mathrm{CRH}$ at level 1 of the PVN. Shown are the montages of representative sections from a placebo, E-, $\mathrm{P}-$, and $\mathrm{E}+\mathrm{P}-$ treated ovariectomized macaques. At this level of magnification, it may be hard to appreciate that the CRH staining is more robust and covered a larger area in the placebo- treated control animal compared to the hormone-treated animals. The staining was quantified as described in the Methods and the results of the 'averaging analysis' are illustrated in Figure 3. At each level of the PVN, the CRH staining was reduced although the variance precluded statistical significance by ANOVA in four of the five levels. However, the E + P-treated group was consistently lower than the placebo group if a $t$-test was applied to only those two groups $(p<0.05$ not shown on graph). Nonetheless, there was a marked and significant decrease in the overall average $\mathrm{CRH}$ staining/section with hormone treatment (ANOVA, $p<0.002$, pixels and microns). Each of the
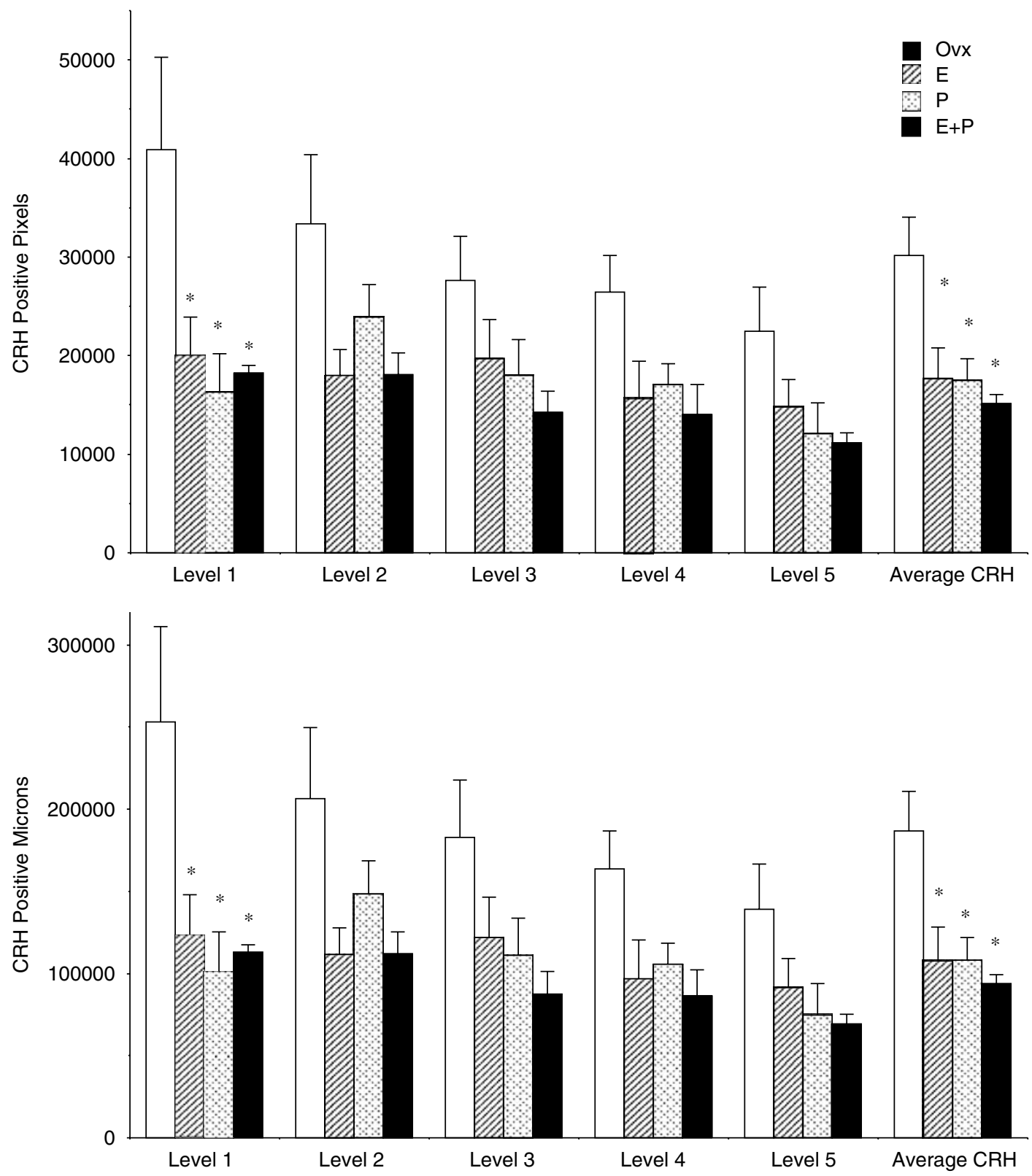

Figure 3 Analysis of $\mathrm{CRH}$ positive pixels (top) and CRH-positive microns (bottom) across five levels of the PVN in each treatment group ( $n=4$ animals/ group). The average $\mathrm{CRH}$ area/level was computed for each animal and then the mean of the animals was obtained for each group. Thus, the variance in the average $\mathrm{CRH}$ represents the variance between the animals of each group. Ovarian hormone treatment significantly reduced the average $\mathrm{CRH}$ signal (ANOVA, $p<0.002$ ). Asterisks represent a significant difference from the control group by Student-Newman-Keul's post hoc pairwise comparison with $p<0.05$. 

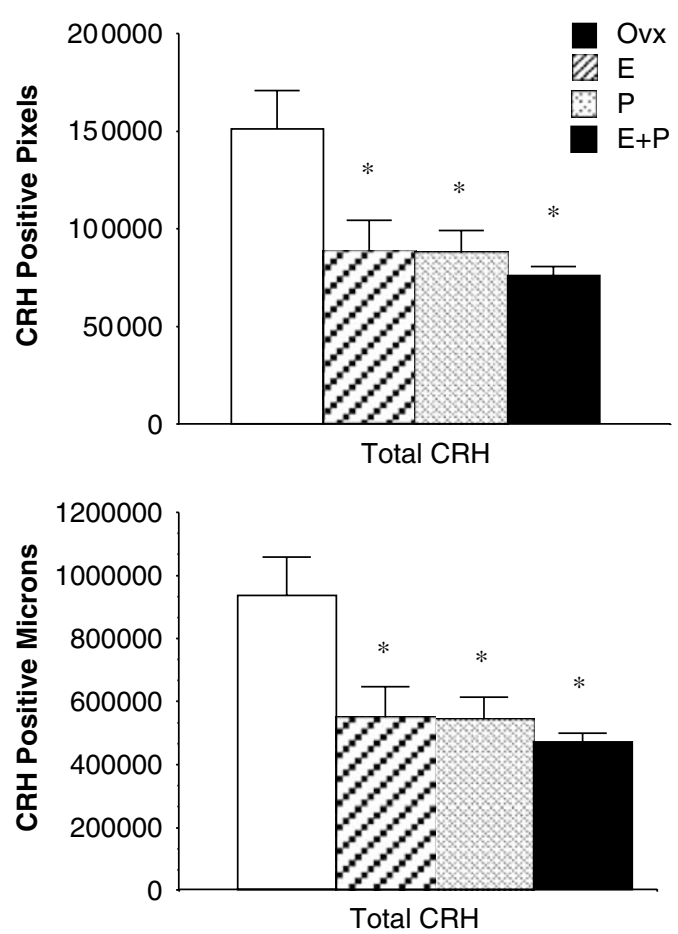

Figure 4 Analysis of total $\mathrm{CRH}$ signal across five levels of the PVN in each treatment group ( $n=4$ animals/group). The positive pixels (top) and positive micron area (bottom) from each level were summed for each animal. The average of the sums of the animals was then obtained and compared. There was a significant difference between groups (ANOVA, $p$ <0.002). Asterisks represent a significant difference from the control group by Student-Newman-Keul's post hoc pairwise comparison at $p<0.05$.

treatment groups exhibited a significant decrease compared to the placebo group (Student-Newman-Keul's, $p<0.05$ ), but there was no difference between the treatment groups. The results of the 'total analysis' are shown in Figure 4. There was significantly less total CRH immunostained area in the animals receiving hormone treatment than in the placebo-treated group (ANOVA, $p<0.002$, pixels and microns). Each of the treatment groups exhibited a significant decrease compared to the placebo group (Student-Newman-Keul's, $p<0.05$ ), but there was no difference between the treatment groups. Figure 5 illustrates the number of $\mathrm{CRH}$ neurons compared to the area (square microns) that was measured. There were significantly fewer $\mathrm{CRH}$ neurons in the PVN, and the average CRF neurons/ section was also significantly less in the hormone-treated groups than in the placebo group (ANOVA $p<0.03$ ). However, there was no difference in the area of PVN that was measured.

Figure 6 shows the CRH mRNA autoradiographic signal in sections at level 2 from a representative animal in each treatment group. In addition, a section that was hybridized to sense CRH riboprobe and a section that was pretreated with RNAse are shown. The agarose gel showing the amplified CRH product of the RT-PCR is also shown. The $\mathrm{CRH}$ product was eluted from this gel for production of the CRH cDNA. The autoradiographic signal for CRH mRNA is markedly denser in the section from the ovariectomized control animal than in the sections from the hormonetreated animals. To quantify the signal, the autoradiograms were captured and the OD and the positive pixel area of the PVN area was obtained with NIH Image as described in the Methods. The results of this analysis are shown in Figure 7. In levels 1-3, ovarian hormone treatment significantly suppressed the CRH OD and positive pixel area (ANOVA $p<0.01$ or less; Student-Newman-Keul's, $p<0.05$, OD and pixels). Moreover, the overall group average of CRH OD per section and positive pixel area per section was significantly reduced by ovarian hormone treatment (ANOVA $p<0.02$ or less; Student-Newman-Keul's $p<0.05$ ).

\section{DISCUSSION}

$\mathrm{CRH}$ was originally isolated from the hypothalamus (Vale et $a l, 1981)$ and its neuroendocrine role in the HPA response to stress is well characterized (Morimoto et al, 1993; Nemeroff, 2004; de Kloet et al, 2005). A new understanding of central CRH action has recently emerged, suggesting its role in the integration of autonomic and behavioral responses to stress. Within the limbic system there is evidence that the CRH system modulates behavioral traits such as locomotor activity, sleep, addictive behavior, and in particular, anxiety related behavior (Dunn and Berridge, 1990; Liebsch et al, 1995). It is also thought that stress-associated dysfunction of CRH neuronal circuitries may be a causal factor in the onset and maintenance of major depression (Holsboer, 1999; Keck and Holsboer, 2001). Moreover, a postmortem study reported that patients with major depressive disorder had significantly more CRH-positive neurons in the PVN than normal controls (Raadsheer et al, 1994).

In the current study, we report that treatment of ovariectomized monkeys with $\mathrm{E}, \mathrm{P}$ or $\mathrm{E}+\mathrm{P}$ for one month reduces CRH mRNA and protein expression in the PVN. However, there was a more pronounced regulation of CRH mRNA in the rostral levels 1-3. This was reflected in the protein expression, significantly at level 1 . The rostral regions of the PVN contain the neuroendocrine CRH neurons, that is, the neurons that project to the median eminence and control the secretion of ACTH (Swanson and Sawchenko, 1983). The CRH neurons that project to other areas of the brain, particularly to the midbrain and periaquaductal gray regions, are present in the caudal twothirds of the PVN (Luiten et al, 1985; Portillo et al, 1998). Together, this information suggests that $\mathrm{E} \pm \mathrm{P}$ can impact the function of the CRH neurons that control the HPA axis.

In general, the immunohistochemical detection of $\mathrm{CRH}$ reflected CRH mRNA. However, CRH mRNA was suppressed to a greater extent in levels 2 and 3 than CRH protein. This may reflect the way in which the immunostaining was segmented from background, yielding positive area, rather than optical density. This approach was chosen because, unlike in situ hybridization results, immunostaining is not considered a perfectly linear reaction that accurately depicts antigen levels, thus rendering optical density of immunostaining somewhat deceptive. Alternatively, there may be changes in translational processes or the stability of $\mathrm{CRH}$, which we are unable to discern. Nonetheless, it appears that a very large decrease in CRH mRNA expression is required to obtain a significant decrease in $\mathrm{CRH}$ immunostaining. 

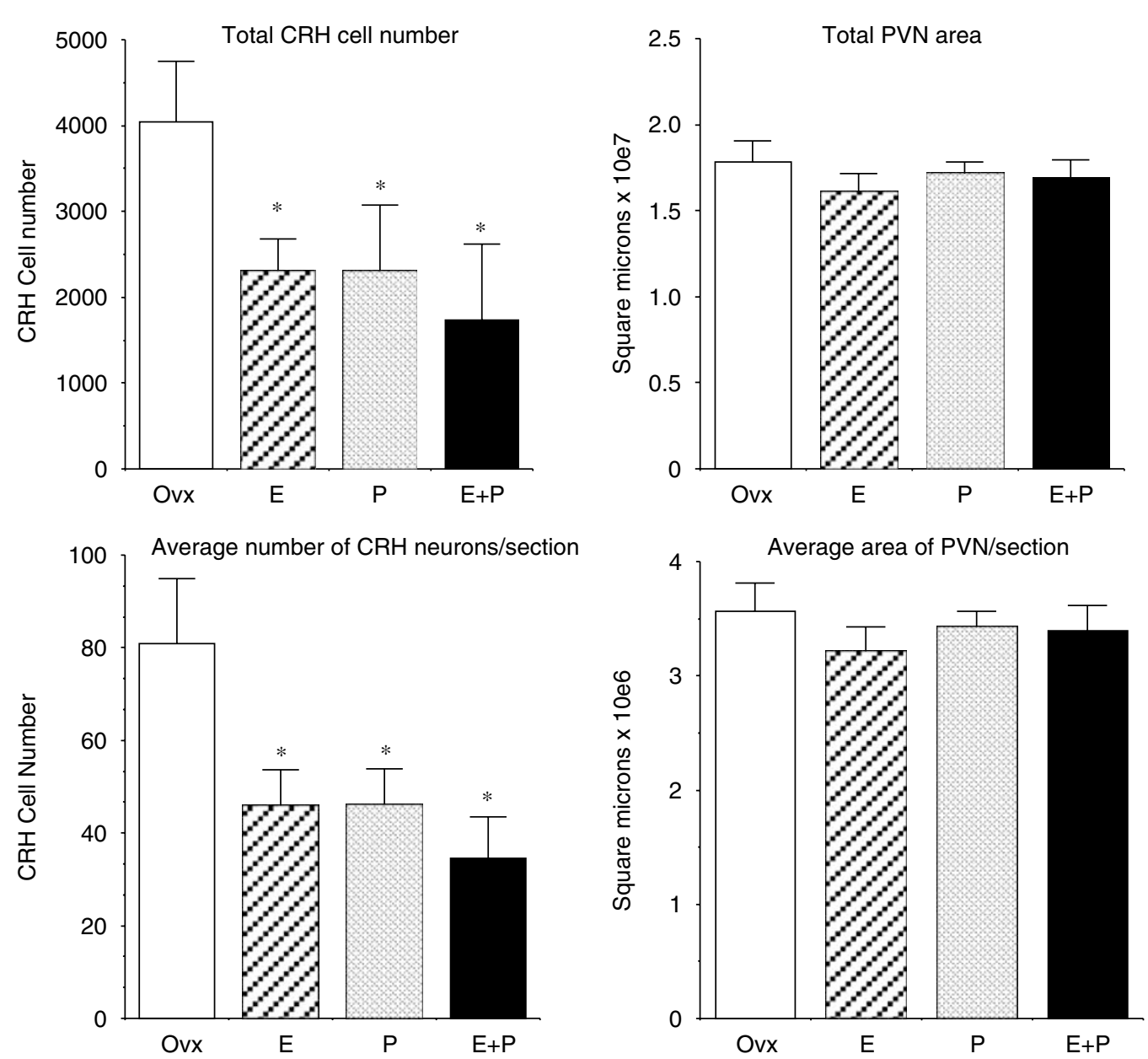

Figure 5 Analysis of $\mathrm{CRH}$ cell number and PVN area across five levels of the PVN in each treatment group ( $n=4$ animals/group). CRH neurons were counted with Slidebook 4.2 by segmenting the positive signal within a defined area of the PVN and counting objects between 5 and I00 voxels (cell size). The defined area of the PVN was obtained in square microns. The left and right sides of the PVN were determined independently and then the cell number and PVN area were summed for each level. In the top panels, the total number of CRH neurons in the PVN and the total area of the PVN that was counted are shown. There is a significant decrease in total detectable CRH neurons with HT (ANOVA, $p<0.03$ ). However, the area of the PVN that was analyzed remained constant across the groups. In the bottom panels, the average number of CRH neurons/section and the average area of the PVN per section are illustrated. There was a significant decrease in the average number of CRH neurons/section with HT (ANOVA, $p<0.03$ ), but the average area of the PVN that was analyzed remained constant. Asterisks indicate that a hormone-treated group was significantly different from the ovariectomized placebo-treated group with Student-Newman-Keul's post hoc pairwise comparison $(p<0.05)$. There was no difference between the hormone-treated groups.

The impact of ovarian steroids on the function of the different components of the HPA axis is of significant importance to women because of their transition into menopause. In the absence of HT, postmenopausal women exhibit higher release of ACTH and cortisol when administered a challenge of dexamethasone plus CRH (Kudielka et al, 1999). In addition, HT reduces pro-inflammatory cytokines in postmenopausal women, which could decrease vulnerability to stress-related sickness (Vural et al, 2006).

A significant portion of our knowledge in this area has been derived from animal studies. Many of these studies initially indicated that treatment of ovariectomized female or male rats with E increased CRH (Li et al, 2003; Lund et al, 2004), which in turn would be expected to increase the activation of the HPA axis in response to stress. Subsequently, it was recognized that acute $\mathrm{E}$ treatment increases $\mathrm{CRH}$, but low-dose chronic E treatment decreased CRH in a stressed rodent model (Dayas et al, 2000). In a primate study, E replacement in a manner that duplicated the preovulatory surge, increased CRH expression in the PVN (Roy et al, 1999). In contrast, 5 days of $\mathrm{E}$ treatment to ovariectomized macaques at a dose similar to our study prevented the elevation in cortisol induced by icv administration of interleukin 1- $\alpha$ (Xia-Zhang et al, 1995). Extending this line of reasoning, duplication of the preovulatory surge of $\mathrm{E}$ in primates may be similar to acute $\mathrm{E}$ treatment in rodents (increases $\mathrm{CRH}$ ), but longerterm $\mathrm{E}$ treatment of IL-injected primates may be similar to chronic E treatment in stressed rodents (decreased CRH or cortisol).

The mechanism by which chronic $\mathrm{E} \pm \mathrm{P}$ decreases $\mathrm{CRH}$ in the primate PVN requires further investigation and there may be multiple factors (Figure 8). Although the human $\mathrm{CRH}$ promoter region contains five half ERE sites (Vamvakopoulos and Chrousos, 1993), questions remain regarding the presence and type of nuclear $\mathrm{E}$ receptors $(\mathrm{ER} \alpha$ 


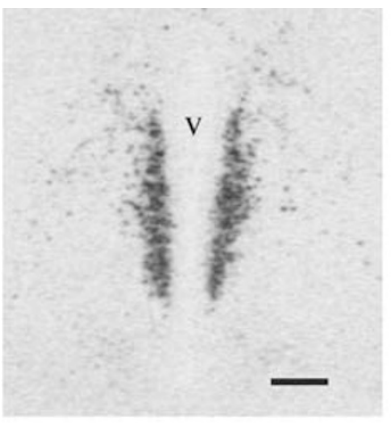

Ovx

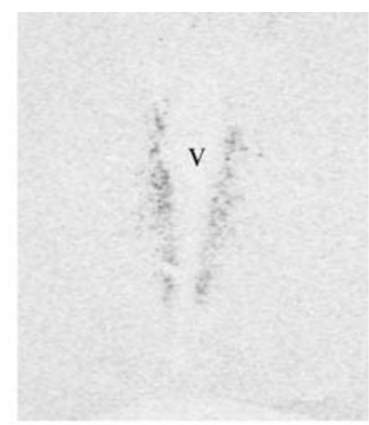

E

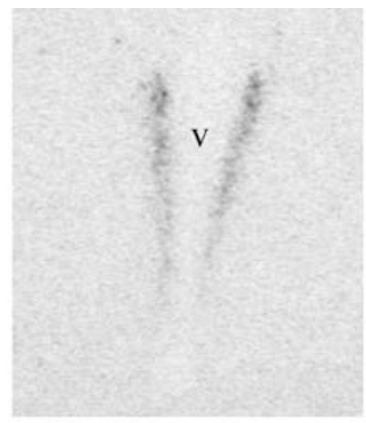

$\mathrm{P}$

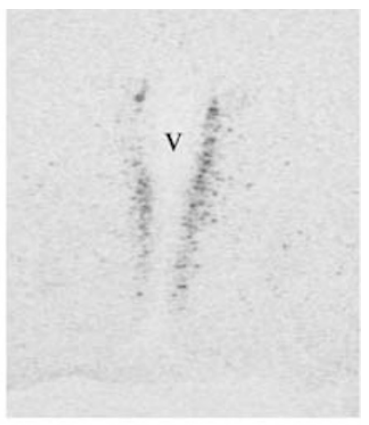

$\mathrm{E}+\mathrm{P}$
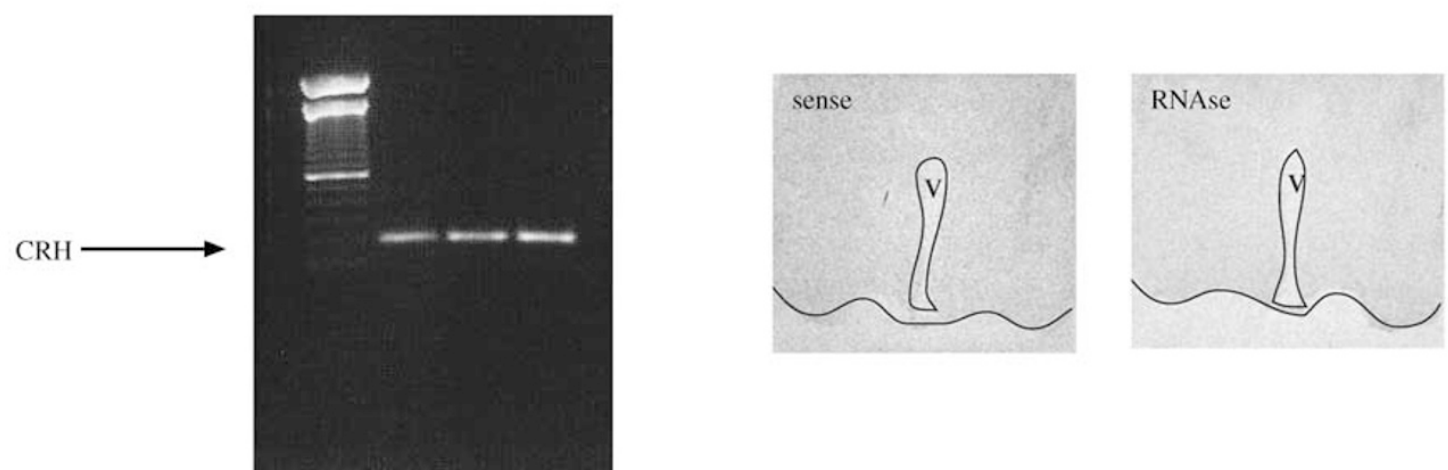

Figure 6 Top panels: in situ hybridization autoradiograms of the PVN at level 2 from representative ovariectomized macaques treated with placebo (ovx), $\mathrm{E}$, $\mathrm{P}$, or estrogen + progesterone $(\mathrm{E}+\mathrm{P})$ for I month. Bottom left panel: agarose gel showing the amplified $\mathrm{CRH}$ fragment used for production of the $\mathrm{CRH}$ cDNA. Bottom right panels: autoradiograms of a section hybridized with sense CRH riboprobe and a section pre-exposed to RNAse before hybridization. There is no signal in either of these negative control sections.

or $\mathrm{ER} \beta$ ) in primate $\mathrm{CRH}$ neurons. $\mathrm{ER} \beta$ was detected in $\mathrm{CRH}$ neurons of rodents (Laflamme et al, 1998; Miller et al, 2004), but ER $\alpha$ was reported in CRH neurons in humans (Bao et al, 2005). We have observed a more robust $\operatorname{ER} \beta$ mRNA signal than ER $\alpha$ in the macaque PVN (Bethea et al, 1996; Gundlah et al, 2000), but further characterization of the steroid receptor compliment of $\mathrm{CRH}$ neurons in different species and at different levels of the PVN is needed. Transfection studies indicated that both ER isoforms weakly or constitutively stimulated CRH expression (Miller et al, 2004), which is consistent with acute, but not chronic, E treatment in vivo.

Afferent innervation may mediate the suppressive effect of $\mathrm{E} \pm \mathrm{P}$ on $\mathrm{CRH}$ and serotonin neurotransmission is a viable candidate. There is a robust serotonergic innervation of the PVN (Petrov et al, 1992, 1994), but most pharmacological studies in rodents indicate that the serotonin system stimulates CRH neurons (Van de Kar, 1991; Fuller, 1992; Hanley and Van de Kar, 2003). Unfortunately, these data have never been reconciled with our understanding that elevation of serotonin increases stress resilience. A recent study showed that repeated citalopram treatment decreased CRH and HPA axis activity in rodents, raising the possibility that discrepancies may be due to chronic versus acute treatments with serotonergic ligands (Moncek et al, 2003).

Selective serotonin reuptake inhibitors that increase available serotonin are antidepressant agents (Owens and Nemeroff, 1994). These agents reportedly reduce the sensitivity of CRH neurons in the PVN as well (Stout et al, 2002) and cortisol levels return to normal in depressed patients treated with a variety of antidepressants (Himmerich et al, 2006; Schule et al, 2006).

We have compiled a body of evidence showing that HT for 1 month with $\mathrm{E}$ or $\mathrm{E}+\mathrm{P}$ acts in the serotonin system of primates in a manner that would increase serotonin neurotransmission (Bethea et al, 2002), and increased serotonin activity is associated with stress resilience (Bethea et al, 2005a). That is, macaques with higher endogenous production of $\mathrm{E}$ and $\mathrm{P}$ and higher expression of genes related to serotonin neurotransmission, maintained ovulatory function upon exposure to a combined stress paradigm of diet, exercise and new housing (Bethea et al, 2005b). The current study demonstrates that the same 1-month HT paradigm that increases serotonin function also decreases CRH expression in the PVN at gene and protein levels.

If serotonin directly inhibited CRH neurons in primates, then the likely candidate receptor is the $5 \mathrm{HT} 1 \mathrm{~A}$ postsynaptic receptor. The 5HT1A receptor is the major inhibitory serotonin receptor, but 5HT1A mRNA expression is not robust in the PVN of macaques and $5 \mathrm{HT} 1 \mathrm{~A}$ binding is decreased and/or desensitized by $\mathrm{E}$ treatment (Gundlah et al, 1999; Lu and Bethea, 2002; Carrasco et al, 2004). 5HT2A and 5HT2C receptors are prominent in the PVN, but they are stimulatory (Gundlah et al, 1999). Hence, it is more likely that inhibitory interneurons, such as GABA neurons, are involved. We found that most of the GABA neurons in the arcuate-infundibular nuclei expressed 5HT2C receptors (Mirkes and Bethea, 2001) and further analysis of the PVN is needed. Indeed, definitive identification of the cohort of 

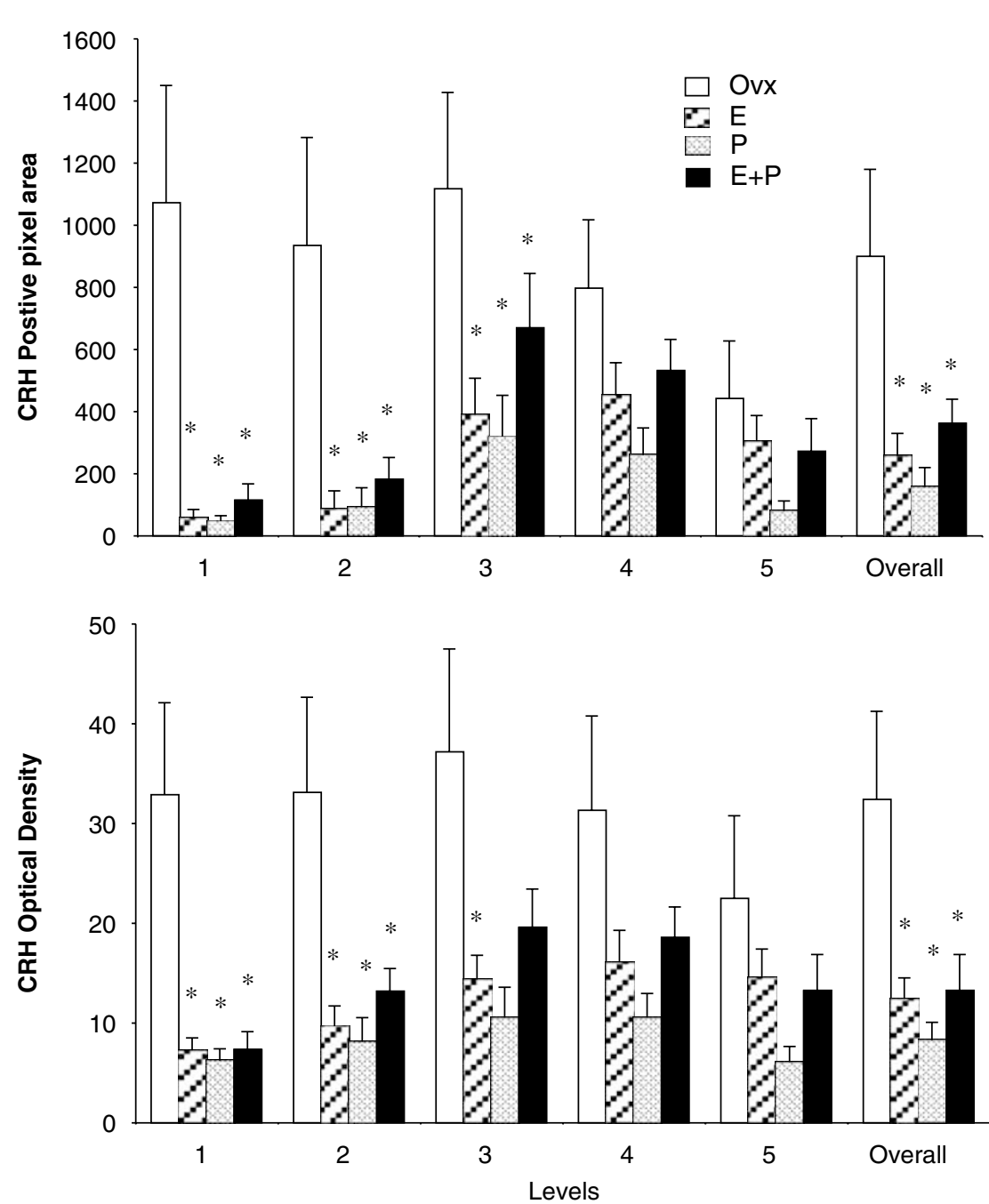

Figure 7 Analysis of CRH mRNA signal on autoradiograms across five levels of the PVN in each treatment group ( $n=4$ animals/group). The top represents the positive pixel area covered by the signal \pm SEM. The bottom illustrates the Optical Density of the signal \pm SEM. There was a significant difference between the treatment groups at levels I, 2, and 3 and in the overall average (ANOVA, $p<0.02$ ). The asterisks indicate significant differences by Student-Newman-Keul's post hoc pairwise comparison with $p<0.05$.

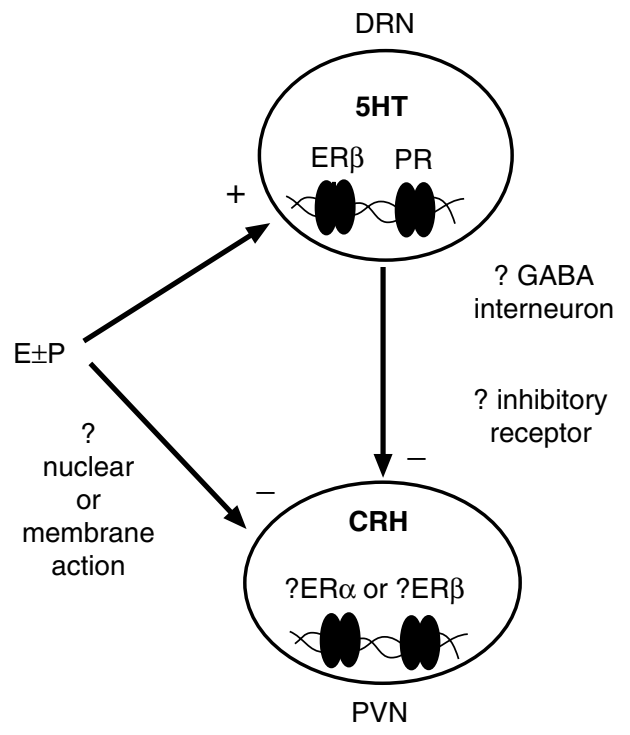

Neuropsychopharmacology steroid and neurotransmitter receptors expressed by CRH neurons would be worth undertaking.

It is notable that $\mathrm{P}$ treatment alone also decreased $\mathrm{CRH}$ mRNA and protein. The mechanism by which this occurs is

Figure 8 A diagrammatic concept illustrating the potential interactions of ovarian hormones, serotonin neurons and $\mathrm{CRH}$ neurons. Ovarian hormones may act on $\mathrm{CRH}$ neurons to decrease $\mathrm{CRH}$ gene expression. This would require a nuclear or membrane receptor, but reports on this are inconsistent between species. This laboratory has shown that HT increases tryptophan hydroxylase production in the dorsal raphe nucleus (Bethea et al, 2000; Sanchez et al, 2005) and serotonin release in the hypothalamus (Centeno et al, 2007). Serotonin neurons express ER $\beta$ and PR for mediation of the action of ovarian hormones (Bethea, 1993, 1994; Gundlah et al, 2000, 200 I). Thus, serotonin innervation of the PVN could mediate the decrease in $\mathrm{CRH}$ expression, but either an inhibitory serotonin receptor is required or more likely, an inhibitory GABA interneuron is present. In this fashion, serotonin could stimulate the GABA neurons, which in turn, could inhibit the $\mathrm{CRH}$ neurons. This type of regulation requires longer-term hormone treatment. 
unknown, but without E priming, there are few nuclear progestin receptors expressed. Nonetheless, during 1 month of treatment, there will be significant amounts of the progestin metabolite, allopregnanalone, produced. In rodents, allopregnanolone attenuated endocrine responses to stress (Patchev et al, 1996) and progesterone, via conversion into allopregnanalone, attenuated $\mathrm{CRH}$-enhanced startle (Toufexis et al, 2004). Moreover, women with PMDD and a history of depression are deficient in the conversion of $\mathrm{P}$ into allopregnanolone (Girdler et al, 2001; Klatzkin et al, 2006). Allopregnenalone can act as an agonist at GABA-A receptors (Barbaccia et al, 2001) and in this fashion, it could produce the same inhibitory effect on CRH neurons as GABA-ergic innervation. Hence, these data indirectly bolster the hypothesis that $\mathrm{E}$ treatment decreases $\mathrm{CRH}$ expression via GABA-ergic innervation. Extrapolating further, in an animal treated with $\mathrm{E}+\mathrm{P}$, there could be a combination of (1) serotonin stimulation of GABA interneurons, which in turn, inhibit CRH neurons, and (2) allopregnenalone acting via inhibitory GABA-A receptors on $\mathrm{CRH}$ neurons. The $\mathrm{CRH}$ immunostaining in the $\mathrm{E}+\mathrm{P}$ group was slightly, but not significantly less than in the $\mathrm{E}$ alone or $\mathrm{P}$ alone treated groups. Thus, if true, these actions do not appear to be additive.

In summary, 1 month of stable, $\mathrm{E}, \mathrm{P}$ or $\mathrm{E}+\mathrm{P}$ treatment of ovariectomized monkeys significantly reduced CRH mRNA and protein in the PVN. Corroborating information points to serotonergic stimulation of GABA-ergic inhibition as a potential mediator of this action. These results suggest that this HT regimen would increase stress resilience in primates.

\section{ACKNOWLEDGEMENTS}

Portions of this study were presented at the 36th annual meeting of the Society for Neuroscience, 14-18, October 2006, Altanta, GA and at the 45th annual meeting of the American College of Neuropsychopharmacology, 3-7, December 2006, Hollywood, FL. We thank Dr Wylie Vale for his generous gift of antiserum to human $\mathrm{CRH}$.

Supported by NIH grants MH62677 to CLB, U54 contraceptive Center Grant HD 18185, and RR000163 for the operation of ONPRC.

\section{DISCLOSURE}

The authors have no financial interests to disclose.

\section{REFERENCES}

Bao AM, Hestiantoro A, Van Someren EJ, Swaab DF, Zhou JN (2005). Colocalization of corticotropin-releasing hormone and oestrogen receptor-alpha in the paraventricular nucleus of the hypothalamus in mood disorders. Brain 128: 1301-1313.

Barbaccia ML, Serra M, Purdy RH, Biggio G (2001). Stress and neuroactive steroids. Int Rev Neurobiol 46: 243-272.

Bethea CL (1993). Colocalization of progestin receptors with serotonin in raphe neurons of macaque. Neuroendocrinology 57: $1-6$.

Bethea CL (1994). Regulation of progestin receptors in raphe neurons of steroid-treated monkeys. Neuroendocrinology 60: $50-61$.
Bethea CL, Brown NA, Kohama SG (1996). Steroid regulation of estrogen and progestin receptor messenger ribonucleic acid in monkey hypothalamus and pituitary. Endocrinology 137: 4372-4383.

Bethea CL, Mirkes SJ, Shively CA, Adams MR (2000). Steroid regulation of tryptophan hydroxylase protein in the dorsal raphe of macaques. Biol Psychiatry 47: 562-576.

Bethea CL, Lu NZ, Gundlah C, Streicher JM (2002). Diverse actions of ovarian steroids in the serotonin neural system. Front Neuroendocrinol 23: 41-100.

Bethea CL, Pau FK, Fox S, Hess DL, Berga SL, Cameron JL (2005a). Sensitivity to stress-induced reproductive dysfunction linked to activity of the serotonin system. Fertil Steril 83: 148-155.

Bethea CL, Streicher JM, Mirkes SJ, Sanchez RL, Reddy AP, Cameron JL (2005b). Serotonin-related gene expression in female monkeys with individual sensitivity to stress. Neuroscience 132: 151-166.

Carrasco GA, Barker SA, Zhang Y, Damjanoska KJ, Sullivan NR, Garcia F et al (2004). Estrogen treatment increases the levels of regulator of $\mathrm{G}$ protein signaling- $\mathrm{Z} 1$ in the hypothalamic paraventricular nucleus: possible role in desensitization of 5-hydroxytryptamine1A receptors. Neuroscience 127: 261-267.

Centeno ML, Reddy AP, Smith LJ, Sanchez RL, Henderson JA, Salli NC et al (2007). Serotonin in microdialysate from the mediobasal hypothalamus increases after progesterone administration to estrogen primed macaques. Eur J Pharmacol 555: 67-75.

Dayas CV, Xu Y, Buller KM, Day TA (2000). Effects of chronic oestrogen replacement on stress-induced activation of hypothalamic-pituitary-adrenal axis control pathways. J Neuroendocrinol 12: 784-794.

de Kloet ER, Joels M, Holsboer F (2005). Stress and the brain: from adaptation to disease. Nat Rev Neurosci 6: 463-475.

Dunn AJ, Berridge CW (1990). Physiological and behavioral responses to corticotropin-releasing factor administration: is CRF a mediator of anxiety or stress responses? Brain Res Brain Res Rev 15: 71-100.

Fuller RW (1992). The involvement of serotonin in regulation of pituitary-adrenocortical function. Front Neuroendocrinol 13: 250-270.

Girdler SS, Straneva PA, Light KC, Pedersen CA, Morrow AL (2001). Allopregnanolone levels and reactivity to mental stress in premenstrual dysphoric disorder. Biol Psychiatry 49: 788-797.

Gundlah C, Kohama SG, Mirkes SJ, Garyfallou VT, Urbanski HF, Bethea CL (2000). Distribution of estrogen receptor beta (ER $\beta$ ) mRNA in hypothalamus, midbrain and temporal lobe of spayed macaque: continued expression with hormone replacement. Mol Brain Res 76: 191-204.

Gundlah C, Lu NZ, Mirkes SJ, Bethea CL (2001). Estrogen receptor beta $(\mathrm{ER} \beta)$ mRNA and protein in serotonin neurons of macaques. Mol Brain Res 91: 14-22.

Gundlah C, Pecins-Thompson M, Schutzer WE, Bethea CL (1999). Ovarian steroid effects on serotonin 1A, 2A and 2C receptor mRNA in macaque hypothalamus. Mol Brain Res 63: 325-339.

Hanley NR, Van de Kar LD (2003). Serotonin and the neuroendocrine regulation of the hypothalamic-pituitary-adrenal axis in health and disease. Vitam Horm 66: 189-255.

Himmerich H, Binder EB, Kunzel HE, Schuld A, Lucae S, Uhr M et al (2006). Successful antidepressant therapy restores the disturbed interplay between TNF-alpha system and HPA axis. Biol Psychiatry 60: 882-888.

Holsboer F (1999). The rationale for corticotropin-releasing hormone receptor (CRH-R) antagonists to treat depression and anxiety. J Psychiatr Res 33: 181-214.

Keck ME, Holsboer F (2001). Hyperactivity of CRH neuronal circuits as a target for therapeutic interventions in affective disorders. Peptides 22: 835-844. 
Klatzkin RR, Morrow AL, Light KC, Pedersen CA, Girdler SS (2006). Histories of depression, allopregnanolone responses to stress, and premenstrual symptoms in women. Biol Psychol 71: 2-11.

Kloet ER (1995). Steroids, stability and stress. Front Neuroendocrinol 16: 416-425.

Kudielka BM, Schmidt-Reinwald AK, Hellhammer DH, Kirschbaum C (1999). Psychological and endocrine responses to psychosocial stress and dexamethasone/corticotropin-releasing hormone in healthy postmenopausal women and young controls: the impact of age and a two-week estradiol treatment. Neuroendocrinology 70: 422-430.

Laflamme N, Nappi RE, Drolet G, Labrie C, Rivest S (1998). Expression and neuropeptidergic characterization of estrogen receptors (ERalpha and ERbeta) throughout the rat brain: anatomical evidence of distinct roles of each subtype. J Neurobiol 36: 357-378.

Li XF, Mitchell JC, Wood S, Coen CW, Lightman SL, O'Byrne KT (2003). The effect of oestradiol and progesterone on hypoglycaemic stress-induced suppression of pulsatile luteinizing hormone release and on corticotropin-releasing hormone mRNA expression in the rat. J Neuroendocrinol 15: 468-476.

Liebsch G, Landgraf R, Gerstberger R, Probst JC, Wotjak CT, Engelmann $M$ et al (1995). Chronic infusion of a CRH1 receptor antisense oligodeoxynucleotide into the central nucleus of the amygdala reduced anxiety-related behavior in socially defeated rats. Regul Pept 59: 229-239.

Lu NZ, Bethea CL (2002). Ovarian steroid regulation of 5HT1A receptor binding and $\mathrm{G}$ protein activation in female monkeys. Neuropsychopharmacology 27: 12-24.

Luiten PG, ter Horst GJ, Karst H, Steffens AB (1985). The course of paraventricular hypothalamic efferents to autonomic structures in medulla and spinal cord. Brain Res 329: 374-378.

Lund TD, Munson DJ, Haldy ME, Handa RJ (2004). Androgen inhibits, while oestrogen enhances, restraint-induced activation of neuropeptide neurones in the paraventricular nucleus of the hypothalamus. J Neuroendocrinol 16: 272-278.

Matthews KA, Berga SL, Owens JF, Flory JD (1998). Effects of short-term suppression of ovarian hormones on cardiovascular and neuroendocrine reactivity to stress in women. Psychoneuroendocrinology 23: 307-322.

Miller WJ, Suzuki S, Miller LK, Handa R, Uht RM (2004). Estrogen receptor (ER)beta isoforms rather than ERalpha regulate corticotropin-releasing hormone promoter activity through an alternate pathway. J Neurosci 24: 10628-10635.

Mirkes SJ, Bethea CL (2001). Oestrogen, progesterone and serotonin converge on GABAergic neurones in the monkey hypothalamus. J Neuroendocrinol 13: 182-192.

Moncek F, Duncko R, Jezova D (2003). Repeated citalopram treatment but not stress exposure attenuates hypothalamicpituitary-adrenocortical axis response to acute citalopram injection. Life Sci 72: 1353-1365.

Morimoto A, Nakamori T, Morimoto K, Tan N, Murakami N (1993). The central role of corticotropin-releasing factor (CRF41) in psychological stress in rats. J Physiol 460: 221-229.

Nemeroff CC (2004). Early-life adversity, CRF dysregulation, and vulnerability to mood and anxiety disorders. Psychopharmacol Bull 38: 14-20.

Owens MJ, Nemeroff CB (1994). Role of serotonin in the pathophysiology of depression: focus on the serotonin transporter. Clin Chem 40: 288-295.

Patchev VK, Hassan AH, Holsboer DF, Almeida OF (1996). The neurosteroid tetrahydroprogesterone attenuates the endocrine response to stress and exerts glucocorticoid-like effects on vasopressin gene transcription in the rat hypothalamus. Neuropsychopharmacology 15: 533-540.

Petrov T, Krukoff TL, Jhamandas JH (1992). The hypothalamic paraventricular and lateral parabrachial nuclei receive collaterals from raphe nucleus neurons: a combined double retrograde and immunocytochemical study. J Comp Neurol 318: $18-26$.

Petrov T, Krukoff TL, Jhamandas JH (1994). Chemically defined collateral projections from the pons to the central nucleus of the amygdala and hypothalamic paraventricular nucleus in the rat. Cell Tissue Res 277: 289-295.

Portillo F, Carrasco M, Vallo JJ (1998). Separate populations of neurons within the paraventricular hypothalamic nucleus of the rat project to vagal and thoracic autonomic preganglionic levels and express c-Fos protein induced by lithium chloride. $J$ Chem Neuroanat 14: 95-102.

Raadsheer FC, Hoogendijk WJ, Stam FC, Tilders FJ, Swaab DF (1994). Increased numbers of corticotropin-releasing hormone expressing neurons in the hypothalamic paraventricular nucleus of depressed patients. Neuroendocrinology 60: 436-444.

Roy BN, Reid RL, Van Vugt DA (1999). The effects of estrogen and progesterone on corticotropin-releasing hormone and arginine vasopressin messenger ribonucleic acid levels in the paraventricular nucleus and supraoptic nucleus of the rhesus monkey. Endocrinology 140: 2191-2198.

Sanchez RL, Reddy AP, Centeno ML, Henderson JA, Bethea CL (2005). A second tryptophan hydroxylase isoform, TPH-2 mRNA, is increased by ovarian steroids in the raphe region of macaques. Brain Res Mol Brain Res 135: 194-203.

Schule C, Baghai TC, Eser D, Zwanzger P, Jordan M, Buechs R et al (2006). Time course of hypothalamic-pituitary-adrenocortical axis activity during treatment with reboxetine and mirtazapine in depressed patients. Psychopharmacology (Berl) 186: 601-611.

Stout SC, Owens MJ, Nemeroff CB (2002). Regulation of corticotropin-releasing factor neuronal systems and hypothalamic-pituitary-adrenal axis activity by stress and chronic antidepressant treatment. J Pharmacol Exp Ther 300: 1085-1092.

Swanson LW, Sawchenko PE (1983). Hypothalamic integration: organization of the paraventricular and supraoptic nuclei. Annu Rev Neurosci 6: 269-324.

Toufexis DJ, Davis C, Hammond A, Davis M (2004). Progesterone attenuates corticotropin-releasing factor-enhanced but not fearpotentiated startle via the activity of its neuroactive metabolite, allopregnanolone. J Neurosci 24: 10280-10287.

Vale W, Spiess J, Rivier C, Rivier J (1981). Characterization of a 41-residue ovine hypothalamic peptide that stimulates secretion of corticotropin and beta-endorphin. Science 213: 1394-1397.

Vamvakopoulos NC, Chrousos GP (1993). Structural organization of the 5' flanking region of the human corticotropin releasing hormone gene. DNA Seq 4: 197-206.

Van de Kar L (1991). Neuroendocrine pharmacology of serotonergic (5HT) neurons. Anim Rev Pharmacol Toxicol 31: 289-320.

Vural P, Akgul C, Canbaz M (2006). Effects of hormone replacement therapy on plasma pro-inflammatory and antiinflammatory cytokines and some bone turnover markers in postmenopausal women. Pharmacol Res 54: 298-302.

Xia-Zhang L, Xiao E, Ferin M (1995). A 5-day estradiol therapy, in amounts reproducing concentrations of the early-mid follicular phase, prevents the activation of the hypothalamo-pituitaryadrenal axis by interleukin-1 alpha in the ovariectomized rhesus monkey. J Neuroendocrinol 7: 387-392. 